\title{
Attempts at a peptide vaccine against paracoccidioidomycosis, adjuvant to chemotherapy
}

\author{
Luiz R. Travassos • Elaine G. Rodrigues • \\ Leo K. Iwai · Carlos P. Taborda
}

Received: 8 August 2007/Accepted: 29 August 2007

(C) Springer Science+Business Media B.V. 2007

\begin{abstract}
Chemotherapy is the basis of treatment of paracoccidioidomycosis in its various forms. Depending on the Paracoccidioides brasiliensis virulence, the status of host immunity, the degree of tissue involvement and fungal dissemination, treatment can be extended for long periods with an alarming frequency of relapses. Association of chemotherapy with a vaccine to boost the cellular immune response seemed a relevant project not only to reduce the time of treatment but also to prevent relapses and improve the prognosis of anergic cases. The candidate immunogen is the gp43 major diagnostic antigen of $P$. brasiliensis and more specifically its derived peptide P10, carrying the $\mathrm{CD}^{+}{ }^{+}$-cell epitope. Both gp43 and P10 protected Balb/c mice against intratracheal infections with virulent $P$. brasiliensis strain. $\mathrm{P} 10$ as single peptide or in a multiple-antigen-peptide
\end{abstract}

L. R. Travassos $(\square) \cdot$ E. G. Rodrigues

Department of Microbiology, Immunology and

Parasitology, Experimental Oncology Unit, Federal

University of São Paulo, Rua Botucatu 862, 8 andar,

São Paulo, SP 04023-062, Brazil

e-mail: travassos@unifesp.br

L. K. Iwai

Section on Immunology and Immunogenetics, Joslin Diabetes Center, Harvard Medical School, Boston, MA, USA

C. P. Taborda

Department of Microbiology, University of São Paulo, São Paulo, SP, Brazil
(MAP) tetravalent construction was protective without adjuvant either by preimmunization and intratracheal challenge or as a therapeutic agent in mice with installed infection. P10 showed additive protective effects in drug-treated mice stimulating a Th-1 type immune response with high IFN- $\gamma$ and IL12. P10 and few other peptides in the gp43 were selected by Tepitope algorithm and actually shown to promiscuously bind several prominent HLA-DR molecules suggesting that a peptide vaccine could be devised for a genetically heterogenous population. P10 was protective in animals turned anergic, was effective in a DNA minigene vaccine, and increased the protection by monoclonal antibodies in Balb/c mice. DNA vaccines and peptide vaccines are promising therapeutic tools to be explored in the control of systemic mycoses.

Keywords Paracoccidioidomycosis . Paracoccidioides brasiliensis - Peptide vaccine . gp43 $\cdot$ P10 $\cdot$ Chemotherapy

\section{Introduction}

Vaccines have been devised with live attenuated or inactivated microorganisms that are injected in the recipient to elicit a protective immune response. Pathogenic organisms may, however, contain products in the complex mixture of immunogenic molecules that cause untoward host responses. 
Prophylactic mild infections may not be acceptable in immune compromised hosts. Isolated protein antigens mainly in the form of recombinant vaccines have alternatively been used as reliable and safer immunogens. In the case of tumor cells, the selection of tumor-specific antigens is important considering the great majority of self nonmutated proteins which do not induce an immune response within the limits of immunological tolerance. Even in autologous tumor cell preparations, there is the possible inclusion, however, of components that may aggravate malignancy. Recombinant proteins, that can be adequately purified for vaccination purposes are still very complex and carry a mixture of epitopes that induce $\mathrm{B}$ cell and $\mathrm{T}$ cell responses. While in many cases a combined response of Th- 2 and T-dependent $\mathrm{B}$ cell lymphocytes with that of Th-1 lymphocytes is most effective for a balanced immune response, there are many cases of immunosuppression or immunological imbalance in which a predominant proinflammatory Th-1 response should be stimulated for effective host protection against infectious agents and tumor cells. Antibodies are beneficial in most cases and constitute the basis of the current human vaccines, but the cells involved in their production synthesize a set of cytokines that may negatively regulate the generally immunoprotective IFN- $\gamma$-mediated Th- 1 response. The idea of reducing even further the size of the immunogen so as to have unique peptide units able to specifically direct the immune response involving $\mathrm{T}-\mathrm{CD}_{4}^{+}, \mathrm{T}-\mathrm{CD}_{8}^{+}$, and B lymphocytes with the perspective of having available timely useful protocols, is a growing concept, although there are no peptidebased vaccines so far approved for human use.

Generally peptides are regarded as unstable, readily degradable molecules with delivery problems to be solved and, in the case of MHC presentation, being restricted by the genetic background of the human recipient. A new comprehension of this area is, however, emerging with new biotechnological perspectives. While each peptide has its clearance in vivo defined by many factors it is also evident that peptides can be modified for increased stability and immunogenicity. Furthermore, the degree of circulation of intradermally or subcutaneously injected peptides can be minimal in the case of dendritic cell uptake and presentation. For distal targets peptides can be administered in liposomes, ISCOMs (immunostimulatory complexes), virosomes, microspheres or in many other associations. Peptides can carry B and $\mathrm{T}$ cell epitopes and target proteins, receptors, tumor cells, virus and microbial cells. As to immunogenetic restrictions peptides can be selected for promiscuity in MHC presentation so that they can still be used in vaccines in a genetically diverse population. Otherwise, a combination of peptides can be used to cover both MHC class I and II restrictions with the aim of fostering immunoprotective responses. From the cautious remarks by Rothbard [1] to the updated views of Purcell et al. [2] it is clear that peptides "display more drug-like properties than recombinant proteins or whole pathogen vaccines". The authors listed 31 peptide-based vaccines at various stages of development against virus and bacterial infections, cancer, malaria, diabetes, Alzheimer's, and other diseases.

In the present review we focus on vaccination attempts against paracoccidioidomycosis with the recent proposition of a peptide vaccine as adjuvant to chemotherapy.

\section{Attempts at devising vaccines against fungal diseases}

Both the innate immune response and the adaptive immunity are important for an antifungal protective effect. Fungi or fungal antigens react with recognition receptors at the surface of macrophages (Toll-like receptors, dectin- 1 , Fc receptors, the mannose receptor, integrins, and other not fully characterized receptors) and activate them to produce cytokines (IL-12, IL-10, IL-18) and chemokines (chemokine receptors CCR2 and CX(3)CR1). Dendritic cells (DCs) which are nondividing terminally differentiated cells link innate and adaptive immunity and activate antigen-specific $\mathrm{T}$ cells. The differentiation of monocytes into DCs demonstrated in human cells has become the essential methodology for the production of DCs to be used in cancer immunotherapy protocols. In the mouse, monocytes generate DCs not only on entry into the lymph and migration to the lymph nodes but also on extravasation from blood and homing to the spleen [3]. Both peripheral blood monocyte subsets with phenotypes Gr1(high)CX(3)CR1(int) and GR1(low)CX(3)CR1(high) can give rise to pulmonary DCs whereas only the latter had the potential to differentiate into lung macrophages [4]. 
Upon maturation, DCs become key antigen-presenting cells (APCs) with increased expression of MHC molecules. Fungal antigens are processed and peptide epitopes presented for recognition by $\mathrm{T}$ lymphocyte receptors. In the case of IL-12-producing DCs Th- 1 cells are induced to proliferate and produce IFN- $\gamma$ and TNF- $\alpha$. IL-12 and IL-18 also stimulate IFN- $\gamma$ production by natural killer (NK) cells. IFN- $\gamma$ activated macrophages have increased fungistatic and fungicidal activities. DCs can also be induced to produce IL-4 which leads to the proliferation of Th-2 lymphocytes that inhibit the protective cell immunity. Nevertheless, Th-2 lymphocytes recognize B-cellpresented antigens and produce cytokines that stimulate B cell maturation and proliferation. Activated B cells produce antibodies that opsonize fungal elements for increased phagocytosis. Opsonization is also achieved with complement and collectins. B cells can also be activated by $\mathrm{T}$ cell-independent antigens generally represented by carbohydrate structures. In a comprehensive review on the development of vaccines against fungal infections, Cutler et al. [5] listed a number of immunogens from pathogenic species that could elicit antibodies and cellular immune responses.

Antibodies were the main mediators of immune protection particularly against Candida spp., Aspergillus spp., Cryptococcus neoformans, and Pneumocystis carinii. Immunogens comprised carbohydrate structures such as $\beta$-1,2-linked mannobiose and mannotriose $[6,7]$ and also $\beta$-1,3-glucan, a candidate for a universal fungal vaccine [8, 9]. Further data on Candida $\beta$-1,2-oligomannosides and specific antibodies to them can be found in Travassos et al. [10]. An interesting aspect was the identification of peptides from a phage library able to mimic $\beta$ 1,2-linked mannoside epitopes [11]. Peptide FHENWPS was specifically recognized by anti- $\beta$ 1,2-oligomannoside monoclonal antibodies (mAb). It inhibited binding of mAb to both live yeast cells and phosphopeptidomannan (PPM). A keyhole limpet hemocyanin (KHL)-peptide conjugate elicited an antibody response to yeast PPM which was inhibited by $\beta$-1,2-mannotetraose.

Idiotypic vaccination with mAb KT4 that neutralizes the antimicrobial activity of Pichia anomala killer toxin (KT) elicited antiidiotypic Abs that were microbicidal and showed in vitro therapeutic effects [12]. Several linear fragments from the mAb variable region showed activities similar to the antibody, and a killer decapeptide (KP) was generated by alanine substitution of the first amino acid of an active 10amino acid fragment. The KP had increased candidacidal activity in vitro and exerted therapeutic effect in established murine models of vaginal and systemic candidiasis, cryptococcosis and paracoccidioidomycosis [13-15]. Noticeable is the fact that laminarin inhibited in a dose dependent manner the cytotoxic activity of KP suggesting that it may react with $\beta-1,3$ glucan molecules at the surface of the yeast forms. Secreted aspartyl proteinase and mannoprotein 65 are two other Candida immunogens that elicit protective antibodies [16].

The mAb (C7), raised against a $C$. albicans cell wall stress mannoprotein, is an IgM that cross-reacted with cell wall proteins Als3 and enolase, as well as with the nuclear pore complex Nup88 [17, 18]. MAb $\mathrm{C} 7$ is the first $\mathrm{Ab}$ able to exert three different antifungal activities against $C$. albicans, namely inhibition of germination and adhesion and a direct fungicidal effect which was extensive to $C$. lusitaniae, Cryptococcus neoformans, Aspergillus fumigatus, and Scedosporium prolificans [19]. Recently, mAb C7 proved to be protective in a murine model of systemic candidiasis [20].

The most well studied antibody protective effect is that directed to glucuronoxylomannan (GXM) from Cryptococcus neoformans [9]. Antibodies to GXM and to oligosaccharides therefrom are protective in animal models of infection and have a potential to be used in the clinical treatment of human cryptococcosis [21]. A heptasaccharide corresponding to the immunodominant motif of serotype A GXM has been produced and it strongly reacted with two different IgM mAbs to GXM. Conjugation of the heptasaccharide to human serum albumin rendered a complex that elicited high-titered $\operatorname{IgG}$ responses in mice administered with complete Freund's adjuvant. Also in this case a peptide mimetic of a GXM epitope, GMDGTQLDRW, was isolated using a protective human $\mathrm{mAb}$. This peptide linked to either BSA or tetanus toxoid elicited a protective antibody response [22].

The major surface glycoprotein (gp120), the p55 and Kexin are Pneumocystis carinii immunogens with protection mechanisms based on antibodies and T-cell dependent and independent but CD40Ldependent, immune responses. In this last case, 
CD4-deficient mice receiving DNA vaccines encoding Kexin and CD40L showed significantly higher anti- $P$. carinii IgG titers and opsonic killing of $P$. carinii compared with those vaccinated with Kexin alone [23].

Immune protection involving $\mathrm{CD} 4{ }^{+} \mathrm{T}$-cells, $\mathrm{CD} 4^{+} \mathrm{T}-$, and $\mathrm{CD}^{+} \mathrm{T}$ cells and $\mathrm{IFN}-\gamma$ has been described for immunogens from $C$. neoformans, Coccidioides spp., and Histoplasma capsulatum (Hsp60) (reviewed in [5]). Generally, a Th-1 response based on IL-12 and IFN- $\gamma$ production is effective against fungal infections. The induction of IL-10 and other type- 2 cytokines is regarded as a limitation to vaccine success. However, depending on the degree of inflammation of the Th-1 response, the Th-2 cytokines are essential for a balanced immune protective response. This balance can be achieved by incorporation of Th-1 and Th-2-stimulating epitopes in the vaccine formulation to achieve protective immunity while keeping the inflammatory response within a tolerable limit. In the immune response against HSP60 from Histoplasma capsulatum or a polypeptide fraction from this protein (F3), production of IL-10 and IFN- $\gamma$ was essential for therapy efficacy. Apparently in this particular case, the cytokine milieu determines the conformation of TCRs making $\mathrm{V} \beta 8.1 / 8.2^{+} \mathrm{T}$ cells essential for the protective effect of HSP60 [24].

A competent $\mathrm{CD}^{+}{ }^{+} \mathrm{T}$ cell response producing IFN $-\gamma$ and $\mathrm{TNF} \alpha$ is usually the chief protective mechanism in fungal infections in addition to specific antibodies as described before. In the course of $\mathrm{CD} 4^{+}-\mathrm{T}$ cell deficiency as in AIDS patients, however, $\mathrm{CD} 8^{+}-\mathrm{T}$ cells could have a protective role and this was examined in Histoplasma-infected mice. In MHC class II-deficient mice infected with $H$. capsulatum, $\mathrm{CD} 8^{+}-\mathrm{T}$ cells were able to limit fungal growth. These cells expressed both IFN $-\gamma$ and granzyme B and were cytotoxic to macrophages containing Histoplasma [25].

Vaccination against Blastomyces dermatitidis using recombinant BAD1 was not much effective even when combined with IL-12 used as adjuvant [26]. Therefore, a genetically engineered $B A D 1$ null mutant was used as a vaccine. Live yeast of the null mutant injected subcutaneously protected mice against a lethal challenge with evidence of sterilizing immunity [27]. Vaccination in IFN- $\gamma$ or TNF$\alpha$ knock-out mice was still effective requiring either the reciprocal cytokine or GM-CSF. As with $H$. capsulatum, antigens from live attenuated yeast can be cross-presented to DCs hence cross-priming $\mathrm{CD}^{+}$T-cells which can function without either TNF- $\alpha$ or IFN $-\gamma$. CD $4^{+}$T-cell independent $\mathrm{CD} 8^{+} \mathrm{T}-$ cell memory in these fungi appeared long lasting (at least 8 weeks post-vaccination). Above all, immunogens from live attenuated fungi seemed to recruit multiple arms of the immune response and be effective even in immunodeficient hosts that can compensate the lack of certain immune mediators (TNF- $\alpha$ or IFN- $\gamma$ ) by substituting elements (GMCSF or TNF- $\alpha$ and GM-CSF, respectively) to render protective immunity [5].

\section{Immunoprophylaxis of paracoccidioidomycosis (PCM)}

Subcutaneous infection with Paracoccidioides brasiliensis was shown to be self-healing inducing strong DTH reactions. The high T-cell reactivity observed in susceptible mice could result in immunoprotection or disease exacerbation depending on the route of a secondary infection [28]. Immunoprotection was obtained with a secondary intraperitoneal challenge associated with persistent cell-mediated immunity of mixed type-1/type-2. In contrast, exacerbated disease followed a secondary intravenous challenge which was associated with anergy and prevalent type-2 immunity. High and low virulence $P$. brasiliensis strains were used to induce immunoprotection in susceptible mice. Immunoprotection was also achieved against a secondary intratracheal infection by virulent $P$. brasiliensis characterized by a combination of $\mathrm{CD}^{+} \mathrm{T}$ cells and $\mathrm{CD} 8^{+} \mathrm{T}$ cells and the production of endogenous IFN- $\gamma$ and IL-12 as well as increased levels of anti- $P$. brasiliensis specific IgG1 and IgG2a antibodies [29].

Although the protection by primary subcutaneous infection with high and low virulence $P$. brasiliensis seemed quite effective against a secondary infection, this model refers to prophylactic vaccination as in other fungal species [5] but not to therapeutic vaccination against the already installed mycosis that will be controlled primarily by chemotherapy. It could, nevertheless, explain the dynamics of multiple infections in endemic areas with few individuals developing progressive disease. 
Gp43 the major diagnostic antigen of

$P$. brasiliensis protects mice against intratracheal challenge by virulent yeast forms

The $43 \mathrm{kDa}$ glycoprotein (gp43) was isolated from $P$. brasiliensis culture supernatant fluids in 1986 [30]. Virtually $100 \%$ of patients with paracoccidioidomycosis had antibodies reacting with gp43. Anti-gp43 antibodies from patients submitted to chemotherapy had lower titers compared with patients with relapsing disease who in turn had antibody titers higher than patients with installed disease. A decrease of anti-gp43 IgG, IgA, and IgM was associated with clinical improvement [31]. Epitopes in gp43 that elicited a strong antibody response were peptidic in nature [32] and different isoforms of gp43 including point mutations and distinct isoelectric points varied in their reactivity with patients'sera. The gp43 gene cloning, sequencing, expression, and its polymorphism have been reviewed elsewhere [33].

Gp43 being secreted in the fungal environment or reaching the blood stream is processed and presented by dendritic cells or B cells inducing a preferential Th-1 or Th-2- type immune response respectively [34, 35].

Immunization with gp43 elicits a vigorous IFN- $\gamma$ mediated $\mathrm{T}-\mathrm{CD} 4{ }^{+}$response that is protective against the intratracheal challenge by virulent yeasts of this fungus. The first report showing that gp43 carried an immunodominant epitope eliciting DTH reactions was that of Rodrigues and Travassos [36]. The T cell epitope responsible for DTH reactions, and $\mathrm{CD}^{+}$ T-cell proliferation, has been mapped to a peptide called P10 with the sequence: QTLIAIHTLAIRYAN [37]. The hexapeptide HTLAIR has been shown to be essential for priming the cellular immune response. Various 12-amino acid peptides derived from P10 with different flanking sequences were able to induce lymphoproliferation in sensitized animals. Both P10 as compared to gp43 was equally protective against the intratracheal challenge of mice with virulent P. brasiliensis. Gp43 shares 50\% identity in the amino acid sequence with the exo- $\beta$-1, 3-D-glucanases from Aspergillus oryzae, Blumeria graminis, Schizosaccharomyces pombe, Pichia augusta, Saccharomyces cerevisae, and Candida albicans. Gp43 has a mutated catalytic site essential for glucanase activity (NKP instead of NEP) and in consequence is not an active enzyme. The nucleotide sequence encoding P10 was conserved which is an important attribute for a vaccine candidate [33, 38]. No epitope for $\mathrm{CD}^{+} \mathrm{T}$ cells was detected in the gp43 but this is by no means a closed matter.

Immunization of Balb/c mice with a mammalian expression vector (VR-gp43) carrying the full gene of gp43 with CMV promoter induced $\mathrm{B}$ and $\mathrm{T}$ cellmediated immune responses protective against the intratracheal challenge by virulent $P$. brasiliensis yeast forms [39]. The amount of IFN- $\gamma$ produced by gp43stimulated lymphoid cells from plasmid immunized mice was comparable to that using a mitogen, therefore indicating a powerful immune response. The cellular immune response in mice immunized with VR-gp43 was maintained for at least 6 months although reduced to half of the stimulation index obtained 15 days after immunization. After 3 months of prime intratracheal infection with $2 \times 10^{5}$ yeast cells of $P$. brasiliensis isolate 1914 of high virulence, mice immunized with VR-gp43 had a significant reduction in CFUs from lungs, spleen and liver, and the histopathological image showed lungs with very few and small granulomas with no detectable fungal cells. One of the advantages of using DNA vaccines is the long-term expression of constituent genes [40] compared to the shorter half-life of recombinant proteins. The VR-gp43 vaccination induced anti-gp43 antibodies of subclasses IgG1 > IgG2a = IgG2b with little IgE, confirming a mixed Th-1/Th-2 immune response.

Historically, protective vaccination with plasmid cDNA encoding a fungal antigen (antigen 2) was reported for the first time against Coccidioides immitis [41] followed by the gp43-DNA vaccine in $P$. brasiliensis one year later [39].

\section{Attempts at formulating a peptide vaccine against paracoccidioidomycosis}

Peptide P10 derived from $P$. brasiliensis gp43 contains the $\mathrm{T}$ cell epitope that is presented by MHC class II molecules from three different mouse haplotypes [37]. The promiscuous nature of P10 was also extended to the HLA-DR alleles since this peptide and the analogous peptide at position gp43 (180-194) without the C-terminal asparagine residue (N-glycosylation site in the original gp43) and with N-terminal lysine, bound to the 9 prevalent Caucasian HLA-DR molecules [42]. 
By using the TEPITOPE algorithm we also looked for additional peptides in the gp43 that could also be promiscuous with respect to HLA-DR binding. This property is essential for a vaccine candidate considering the genetic diversity of the target population. In terms of lymphoproliferation, gp43 (180-194) was recognized by $53 \%$ of patients with treated PCM and the other promiscuous peptides were recognized by $32-47 \%$ of patients; $74 \%$ of patients recognized the combination of 5 promiscuous gp43 peptides [42]. An expansion of this study with 10 more patients (total of 29) showed that $79 \%$ of PCM patients recognized at least one peptide, and by pooling peptides gp43 (4559), gp43 (94-108), gp43 (106-120), gp43 (181-195) or P10, and gp43 (283-298) the recognition frequency increased to $86 \%$ [43]. The TEPITOPE algorithm scanned 25 Caucasian HLA-DRs and P10 and neighboring peptides were predicted to bind to $90 \%$ or more of these molecules.

A reduced number of healthy individuals had PBMC proliferating with gp43 and even fewer with gp43 derived peptides. Possibly, these individuals may have been exposed to $P$. brasiliensis on a trip to reserve areas of the fungus or cross-reacted with related fungal antigens, possibly also exo- $\beta-1,3-\mathrm{D}-$ glucanases. Looking for sequences homologous to that of P10 in data banks we found indeed similar sequences in $\beta$-1,3-glucanases from Aspergillus nidulans, Histoplasma capsulatum, Blastomyces dermatitidis, and Lacazia loboi (a gp43-like protein). However, similar sequences were also found in different proteins from a series of bacteria, protozoa, and even fowl (Gallus gallus). Some of these peptide sequences were predicted by the TEPITOPE algorithm to bind to HLA-DR molecules (at 3\% threshold) in a way similar to P10. While P10 from P. brasiliensis was recognized by 21 of 24 HLA-DR alleles, the peptide from $A$. nidulans would bind to 18/24 in great contrast with peptides from $H$. capsulatum and $B$. dermatitidis that showed a very poor recognition, 5/24 and 3/24 respectively (Table 1 ). It seems then that the P10 homologous peptides from related proteins of $H$. capsulatum and $B$. dermatitidis are not vaccine candidates for a MHC class IIrestricted T-cell activation. Remarkably, completely unrelated species as Plasmodium yoelli and Streptococcus gordonii had hypothetical proteins with homologous peptides being recognized by a high number of HLA-DR molecules (21/24).

\section{Strategic use of peptide vaccine}

Stimulation of an effective IFN- $\gamma$-producing T-helper response can simultaneously trigger the production of potentially protective antibodies and the activation of $\mathrm{CD}^{+} \mathrm{T}$ cells in addition to activation of phagocytic cells. In the presence of several immunogenic molecules of the fungal agent, stimulation of one arm of the immune system may alter a state of early or installed immunosuppression. It is possible then that, once complying with the MHC class II restrictions, a vaccine could be effective primarily with a peptide inducing a robust Th- 1 immune response. But fungal infections are regularly treated with drugs, therefore a peptide vaccine can function as an adjuvant to reduce the time of treatment, avoid frequent relapses, improve treatment of anergic cases, and cope with fungal drug resistance. To expect that a vaccine made of a polysaccharide, a glycoprotein or peptide (s) may alone sterilize a massive experimental infection or an acute or progressive mycosis in patients without the concomitant use of fungistatic/ fungicidal drugs is not realistic. One should, therefore, test the prospective vaccine to be introduced as an adjuvant to chemotherapy. Successful drug treatment can lyse a great number of fungal cells and the liberated cell contents may enhance a Th-2/B cell response with nonprotective antibodies. As the fungal load is reduced specific antibody titers also wane. Endogenous or vaccine stimulated specific Th-1 response should help to balance the immune response, increase the fungal clearance and shorten the recovery period.

Experiments with Balb/c mice that respond quite well to P10 immunization in terms of IFN- $\gamma$ production and anti-fungal protection effects, served to confirm some of these expected responses.

P10 immunization was coupled to chemotherapy in intratracheally infected Balb/c mice using two protocols. Infected mice with yeast cells of highly virulent $P$. brasiliensis underwent P10 and/or drug treatment starting after $48 \mathrm{~h}$ of infection. In the second protocol, P10 and/or drug treatment started after 30 days infection. The treatment continued for 30 days, during which groups of mice received intraperitoneal doses of itraconazole, fluconazole, ketoconazole, sulfamethoxazole or trimethoprim-sulfamethoxazole every $24 \mathrm{~h}$. Amphotericin B was administered every $48 \mathrm{~h}$. Immunization with P10 
Table 1 In silico prediction of HLA-DR binding of various peptides, homologous to P. brasiliensis P10, from proteins of different species

\begin{tabular}{|c|c|c|c|c|}
\hline Species & Protein description & $\begin{array}{l}\text { Position from } \\
\mathrm{N}-\mathrm{t}^{\mathrm{a}} \text { methionine }\end{array}$ & $\begin{array}{l}\text { Sequence(mostly from } \\
\text { BLAST/NCBI data base) }\end{array}$ & $\begin{array}{l}\text { Number } \\
\text { of HLA-DR } \\
\text { molecules } \\
\text { recognized } \\
\text { (at } 3 \% \text { threshold) }\end{array}$ \\
\hline P. brasiliensis & gp43 & $181-195$ & Q T L I A I H T L A I R Y A N & 21 \\
\hline $\begin{array}{l}\text { Aspergillus } \\
\text { nidulans }\end{array}$ & $\begin{array}{l}\text { glucanase-like } \\
\text { protein }\end{array}$ & $251-266$ & E Q T I L A F E T L A Q R Y L & 18 \\
\hline $\begin{array}{l}\text { Histoplasma } \\
\text { capsulatum }^{b}\end{array}$ & $\beta$-glucanase & $180-194$ & A Q T L N A L R A L A E R Y A & 5 \\
\hline $\begin{array}{l}\text { Blastomyces } \\
\quad \text { dermatitidis }\end{array}$ & $\beta$-1,3-glucanase & $185-199$ & A Q T L N A V R A L A E R Y A & 3 \\
\hline $\begin{array}{l}\text { Bacillus } \\
\quad \text { thurigiensis } \\
\text { Bacillus cereus }\end{array}$ & $\begin{array}{l}\text { transcriptional } \\
\text { regulator Ara C family }\end{array}$ & $236-252$ & N N G I I A I - T L A I R Y A I D G & 4 \\
\hline Lacazia loboi & gp43-like protein & $\begin{array}{l}\text { AAW } 21849^{c} \\
21-37\end{array}$ & K Q T L A A I R A L A N R Y A K R & 13 \\
\hline Gallus gallus & $\begin{array}{l}\text { ortholog of } \\
\text { rat PB-cadherin }\end{array}$ & $545-563$ & K G T L L A V H T L A V S Y T A G V D & 13 \\
\hline $\begin{array}{l}\text { Herpetosiphon } \\
\text { auranticus }\end{array}$ & $\begin{array}{l}\text { UDP-N-acetylmuramoyl } \\
\text { alanyl-D-glutamyl- } \\
\text { 2,6-dipimelate- } \\
\text { D-alanyl-D-alanyl ligase }\end{array}$ & $114-131$ & V D Q T L T A M H R L A T R Y R Q Q & 12 \\
\hline $\begin{array}{l}\text { Desulfotalea } \\
\text { psychrophila }\end{array}$ & $\begin{array}{l}\text { Similar to dolichyl } \\
\text { phosphate mannose } \\
\text { synthase }\end{array}$ & $284-300$ & A L P L I A C H T L A I I Y F C C & 18 \\
\hline $\begin{array}{l}\text { Plasmodium } \\
\text { yoelli yoelli }\end{array}$ & Hypothetical protein & $\begin{array}{r}\text { XP727303 } \\
786-803\end{array}$ & I E L L I S I L T L S I R Y I L R N & 21 \\
\hline $\begin{array}{l}\text { Streptococcus } \\
\text { gordoni }\end{array}$ & Hypothetical protein & $477-491$ & G L S M I H T L A I I Y A V V & 21 \\
\hline Gibberella zeae & Hypothetical protein & $27-42$ & L N S Q T I A I H T L A H Q D S & 3 \\
\hline $\begin{array}{l}\text { Rhodococcus } \\
\text { erythropolis }\end{array}$ & Hypothetical protein & $65-81$ & F G G L I A S G I H T L A I L Q R & 10 \\
\hline
\end{tabular}

${ }^{\text {a }} \mathrm{N}$-t, N-terminal

b Data base for H. capsulatum, Hc, and B. dermatitidis, Bd (http://www.genome.wustl.edu/)

c Assession number in the BLAST/NCBI data base, for incomplete sequence indicating the corresponding peptide fragment

was carried out weekly for 4 weeks, once in complete Freund's adjuvant and three times in incomplete Freund's adjuvant [44].

A significant reduction in the fungal load (measured as CFUs) was observed in both groups, either immunized with P10 only or treated with antifungal drugs, with an additive protective effect obtained with the combination of both. Unexpectedly, animals treated with sulfamethoxazole, showed early protection followed by relapse, but the association of sulfamethoxazole and P10 vaccination successfully controlled the infection. With the second protocol that aimed to reproduce the patient's condition of established infection, the fungal burden was examined after 60 and 120 days of infection. Also in this case, an additive protective effect of P10 immunization and drug treatment was observed, with 60 to $80 \%$ reduction in lung CFUs. As examined in lung homogenates chemotherapy led to a predominant Th2 response with increased production of IL-4 and IL-10 as hypothesized above. P10 vaccination stimulated a Th1 response, rich in IFN- $\gamma$ and IL-12 
without suppressing the Th-2 elements of the immune response [44]. It should be pointed out that these experiments could be further optimized with prolonged treatment aiming complete infection control.

In acute or subacute forms of PCM patients may have high antibody titers accompanied by severe depression of cell-immunity [45]. In an attempt to experimentally reproduce these conditions, Balb/c mice were treated with dexamethasone- 21 phosphate added to drinking water. After 30 days animals showed negative DTH. Infected animals, treated with $0.15 \mathrm{mg} / \mathrm{kg}$ of dexamethazone and injected with $P$. brasiliensis crude antigen also showed negative DTH after the same period. Mice were then infected with a virulent $P$. brasiliensis isolate and after fifteen days were submitted to chemotherapy and/or P10 immunization. The association of drugs and P10 immunization conferred additive protection. A significant increase in IL-12 and IFN- $\gamma$ and decrease of IL-4 and IL-10 was observed in mice immunized with P10 alone or in association with antifungal drugs [Marques et al., unpublished results]. These results suggest that P10 immunization can be effective in the case of anergic patients.

\section{Peptide delivery and adjuvants}

Peptide delivery using formulations that did not include CFA has also been a concern of our group. Immunization with the P10 minigene in plasmid DNA associated or not with a plasmid carrying a murine IL-12 insert, was tested in Balb/c mice intratracheally infected with a virulent isolate ( $\mathrm{Pb} 18)$ of $P$. brasiliensis. Such immunization elicited significant reduction of fungal burden in lung, spleen, and liver. A significant production of IL-12 and IFN- $\gamma$ and reduction of IL-4 levels in lung homogenates were observed with the DNA vaccination [Rittner et al., unpublished results].

Another attempt involved a MAP (multiple antigen peptide) construction. MAP-10 or M10 had four equal LIAIHTLAIRYAN (N-terminal QT-less P10) chains synthesized on a branched lysine core containing glycine at the C-terminal position. Proliferation of lymph node cells from P10 or M10sensitized mice was identical when stimulated in vitro with either P10 or M10. Mice immunized with a single dose of M10 without adjuvant and challenged i.t. with $P$. brasiliensis showed fewer lung, spleen and liver CFUs and few or no yeasts in lung histopathological sections [46].

In Balb/c mice with established 30-day intratracheal infection, the therapeutic effect of P10 was tested alone or mixed with adjuvants: alum, monophosphoryl lipid A or complete Freund's adjuvant (Fig. 1). Surprisingly, P10 administered in PBS was the most effective preparation with a very significant reduction in the CFUs from the lungs with no fungi detected in spleens and livers. Modifications of $\mathrm{N}$ and C termini of a peptide are known to prevent its degradation by exopeptidases [47]. Such modifications usually involve $\mathrm{N}$-acetylation and $\mathrm{C}$-amidation. In the experiments described, P10 was always used in the C-amidated form.

\section{Association of P10 and protective anti-gp43 monoclonal antibodies}

An association of $\mathrm{P} 10$ with protective anti-gp43 mAbs has also being explored. Recently, it has been reported that anti-gp70 mAbs were protective against experimental PCM [48]. Both gp43 and gp70 are markers for monitoring the regression of PCM through their decreased antigenemia and specific antibody response in patients submitted to chemotherapy $[49,50]$.

The protective effect of anti-gp43 mAbs injected i.p. on the intratracheal infection with $P$. brasiliensis was examined in Balb/c mice (unpublished results). The reactivity of $\mathrm{mAb} 3 \mathrm{E}$, the most efficient $\mathrm{mAb}$ in the reduction of fungal burden and phagocytosis in vitro, against a panel of gp43 derived peptides suggested that the recognized epitope could lie within the sequence NHVRIPIGYWAV shared with Aspergillus fumigatus, A. oryzae and B. graminis internal sequences of $\beta$-1,3-glucanases. This peptide would represent with $\mathrm{P} 10$, another candidate for a peptide vaccine against PCM.

In a P10-preimmunization protocol, which is not the most effective in the absence of a simultaneous infection and chemotherapy, mAbs were tested as protective agents. The association of P10-preimmunization and $\mathrm{mAb} 3 \mathrm{E}$ administered $24 \mathrm{~h}$ before intratracheal challenge with virulent $P$. brasiliensis yeasts resulted in the best protection using short-term protocols in comparison with a nonprotective mAb. 


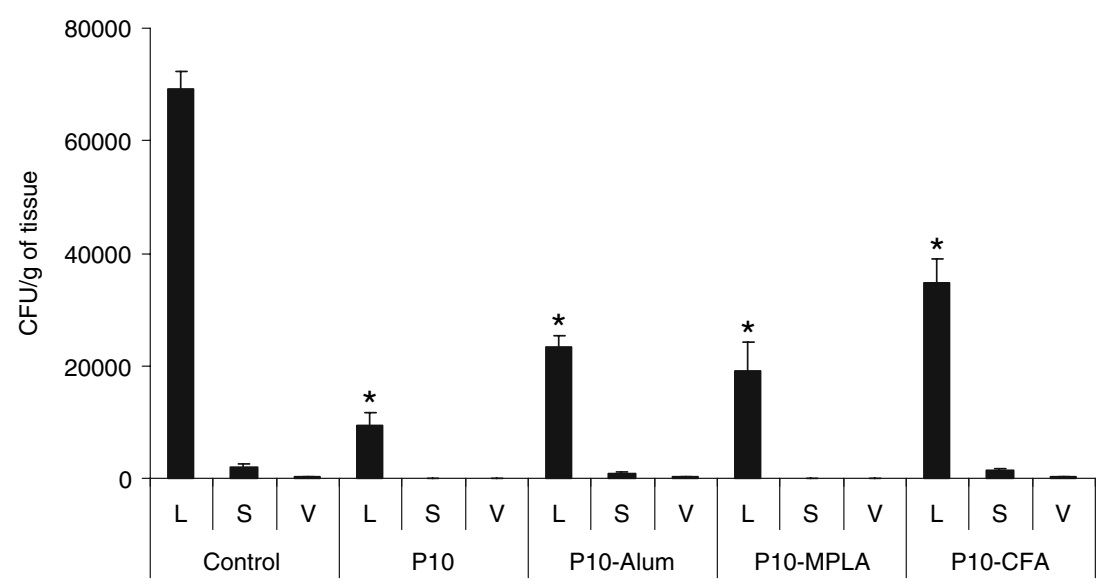

Fig. 1 Therapeutic effect of P10 administered alone or with adjuvants. Balb/c mice (five per group) were infected with $3 \times 10^{5}$ cells of Paracoccidioides brasiliensis $\mathrm{Pb} 18$ and after 30 days vaccination with P10 alone or mixed with adjuvants was initiated. P10 was diluted in $20 \%$ DMSO and PBS and administered at $20 \mu \mathrm{g}$ per animal. Alum and complete Freund's adjuvant (CFA) were used in the same volume $(50 \mu \mathrm{l})$ as for P10 solution. Monophosphoryl lipid A (MPLA) was used at $1 \mu \mathrm{g}$ per animal. Thirty days after therapy mice were sacrificed totaling 90 days of infection. Colony forming units (CFUs) were determined in the lung $(\mathrm{L})$, spleen $(\mathrm{S})$ and liver $(\mathrm{V})$ of mice. Values are means with standard deviations

Table 2 Association of monoclonal antibody against gp43 and immunization with P10 in Balb/c mice infected i.t. for 45 days (short period) with $P$. brasiliensis isolate $\mathrm{Pb} 18$

\begin{tabular}{|c|c|c|c|c|c|}
\hline \multirow{2}{*}{$\begin{array}{l}\text { Balb/c mice }{ }^{\mathrm{a}} \\
\text { Treatment }^{\mathrm{b}}\end{array}$} & \multirow{2}{*}{$\begin{array}{l}\text { Lung CFUs }{ }^{\mathrm{e}} \\
\mathrm{CFU} / \mathrm{g} \text { tissue }\end{array}$} & \multicolumn{4}{|c|}{ Cytokine (ng/g/ml) } \\
\hline & & IL-4 & IL-10 & IL-12 & IFN- $\gamma$ \\
\hline Sham infection & - & $0.81 \pm 0.38$ & $1.30 \pm 0.60$ & $5.56 \pm 2.41$ & $0.33 \pm 0.39$ \\
\hline Only infected ${ }^{\mathrm{c}}$ & $26,185 \pm 2,914$ & $1.44 \pm 0.16$ & $2.87 \pm 1.27$ & $11.02 \pm 0.564$ & $0.78 \pm 0.57$ \\
\hline Immunized P10 & $13,291 \pm 1,551$ & $1.26 \pm 0.16$ & $7.54 \pm 1.01$ & $15.30 \pm 2.39$ & $7.42 \pm 1.53$ \\
\hline $\mathrm{mAb} 32 \mathrm{H}$ (nonprotective) $^{\mathrm{d}}$ & $31,523 \pm 7,991$ & $1.20 \pm 0.25$ & $13.40 \pm 2.17$ & $4.28 \pm 6.52$ & $3.20 \pm 1.35$ \\
\hline $\mathrm{mAb} 3 \mathrm{E}{\text { (protective })^{\mathrm{d}}}$ & $19,220 \pm 2,279$ & $1.23 \pm 0.17$ & $11.12 \pm 0.14$ & $13.50 \pm 1.52$ & $6.35 \pm 0.68$ \\
\hline $\mathrm{P} 10$ and $\mathrm{mAb} 32 \mathrm{H}$ & $20,924 \pm 4,359$ & $1.39 \pm 0.01$ & $9.15 \pm 1.53$ & $10.78 \pm 2.51$ & $5.06 \pm 0.86$ \\
\hline $\mathrm{P} 10$ and $\mathrm{mAb} 3 \mathrm{E}$ & $8,800 \pm 1,886$ & $0.75 \pm 0.17$ & $6.89 \pm 1.88$ & $22.24 \pm 1.77$ & $8.87 \pm 1.44$ \\
\hline
\end{tabular}

a Male, 6-8 week-old Balb/c mice, groups of 10

b Animals were preimmunized with P10 (4 doses of $20 \mu \mathrm{g}$, the first in CFA and the others in IFA ) before infection

c Intratracheal infection with $3 \times 10^{5} \mathrm{~Pb} 18$ yeast forms

d Antibodies purified in protein A and LPS-removing detoxigel injected i.p. $24 \mathrm{~h}$ before i.t. challenge

e CFUs, colony forming units

Significantly, this association yielded the highest IFN- $\gamma$ and IL-12 levels and fewest lung CFUs (Table 2).

Short-term protocols (30 to 45 days) have the advantage of allowing repeated experiments to define a certain response. However, longer periods of treatment and observation may lead to even more effective results, aiming at sterilization in experimental models with massive infection loads.

\section{Concluding remarks}

Chemotherapy is the basic treatment of systemic mycoses. In cases of immunodepression and even of anergy the fungal elements, usually yeast forms, proliferate intensely because of deficient innate and adaptive immune response. In these conditions, chemotherapy is less efficient and requires long periods of treatment with the risk of relapsing 
disease. Therapeutic vaccination with fungal antigens may boost the cell immune response and add to the protective effect of chemotherapy even counteracting the possibility of relapsing disease.

Of all prospective vaccines, DNA-based vaccines and peptides appear as the most promising because they can be obtained in large quantities at high degrees of purity for human immunization. The results with $\mathrm{P} 10$ show that a single peptide had a remarkable therapeutic effect even without adjuvant. It also showed that protection can be achieved in mice with established disease, undergoing chemotherapy, by stimulating one arm of the immune response, that of IFN- $\gamma$-mediated $\mathrm{CD} 4^{+}$T-cells. The present results also show that monoclonal antibodies can be protective against paracoccidioidomycosis and that a new peptide, carrying a $\mathrm{B}$ cell epitope can also be tested in a vaccine to foster a balanced immune response.

Acknowledgments The authors thank Fundação de Amparo a Pesquisa do Estado de São Paulo (Fapesp) for research grants and the National Research Council $(\mathrm{CNPq})$ for career fellowships.

\section{References}

1. Rothbard JB. Synthetic peptides as vaccines. Biotechnology 1992;20:451-65.

2. Purcell AW, McCluskey J, Rossjohn J. More than one reason to rethink the use of peptides in vaccine design. Nature Revs 2007;6:404-14.

3. León B, Martínez del Hoyo G, Parrillas V, Vargas HH, Sánchez-Mateos P, Longo N, López-Bravo M, Ardavín C. Dendritic cell differentiation potential of mouse monocytes: monocytes represent immediate precursors of CD8- and CD8+ splenic dendritic cells. Blood 2004;103:2668-76.

4. Landsman L, Varol C, Jung S. Distinct differentiation potential of blood monocyte subsets in the lung. J Immunol 2007;178:2000-7.

5. Cutler JE, Deepe Jr GS, Klein B. Advances in combating fungal diseases: vaccines on the threshold. Nature Revs 2007;5:13-28.

6. Han Y, Riesselman MH, Cutler JE. Protection against candidiasis by an immunoglobulin G3 (IgG3) monoclonal antibody specific for the same mannotriose as an IgM protective antibody. Infect Immun 2000;68:1649-54.

7. Zhang MX, Cutler JE, Han Y, Kozel TR. Contrasting roles of mannan-specific monoclonal immunoglobulin $\mathrm{M}$ antibodies in the activation of classical and alternative pathways by Candida albicans. Infect Immun 1998;66:6027-9.

8. Torosantucci A, Bromuro C, Chiani P, De Bernardis F, Berti F, Galli C, Norelli F, Bellucci C, Polonelli L,
Costantino P, Rappuoli R, Cassone A. A novel glycoconjugate vaccine against fungal pathogens. J Exp Med 2005;202:597-606.

9. Casadevall A, Pirofski LA. Polysaccharide-containing conjugate vaccines for fungal diseases. Trends Mol Med 2006;12:6-9.

10. Travassos LR, Rodrigues ML, Nimrichter L. Antigenic oligosaccharides, structure and immunobiological relevance. In: Verli $H$ (eds) Insights into carbohydrate structure and biological function, Transworld Research Network, Kerala, India; 2006, p. 109-46.

11. Jouault T, Fradin C, Dzierszinski F, Borg-Von-Zepelin M, Tomavo S, Corman R, Trinel PA, Kerckaert JP, Poulain D. Peptides that mimic Candida albicans-derived beta-1,2linked mannosides. Glycobiology 2001;11:693-701.

12. Cassone A, Conti S, De Bernardis F, Polonelli L. Antibodies, killer toxins and antifungal immunoprotection: a lesson from nature? Immunol Today 1997;18:164-9.

13. Polonelli L, Magliani W, Conti S, Bracci L, Lozzi L, Neri P, Adriani D, De Bernardis F, Cassone A. Therapeutic activity of an engineered synthetic killer antiidiotypic antibody fragment against experimental mucosal and systemic candidiasis. Infect Immun 2003;71:6205-12.

14. Cenci E, Bistoni F, Mencacci A, Perito S, Magliani W, Conti S, Polonelli L, Vecchiarelli A. A synthetic peptide as a novel anticryptococcal agent. Cell Microbiol 2004;6:953-61.

15. Travassos LR, Silva LS, Rodrigues EG, Conti S, Salati A, Magliani W, Polonelli L. Therapeutic activity of a killer peptide against experimental paracoccidioidomycosis. J Antimicrob Chemother 2004;54:956-8.

16. De Bernardis F, Boccanera M, Adriani D, Spreghini E, Santoni G, Cassone A. Protective role of antimannan and anti-aspartyl proteinase antibodies in an experimental model of Candida albicans vaginitis in rats. Infect Immun 1997;65:3399-405.

17. Omaetxebarría MJ, Moragues MD, Elguezabal N, Rodríguez-Alejandre A, Brena S, Schneider J, Polonelli L, Pontón J. Antifungal and antitumor activities of a monoclonal antibody directed against a stress mannoprotein of Candida albicans. Curr Mol Med 2005;5:393-401.

18. Brena S, Omaetxebarria MJ, Elguezabal N, Cabezas J, Moragues MD, Ponton J. Fungicidal monoclonal antibody C7 binds to Candida albicans Als3. Infect Immun 2007;75:3680-2.

19. Moragues MD, Omaetxebarria MJ, Elguezabal N, Sevilla MJ, Conti S, Polonelli L, Ponton J. A monoclonal antibody directed against a Candida albicans cell wall mannoprotein exerts three anti- $C$. albicans activities. Infect Immun 2003;71:5273-9.

20. Sevilla MJ, Robledo B, Rementeria A, Moragues MD, Ponton J. A fungicidal monoclonal antibody protects against murine invasive candidiasis. Infect Immun 2006;74:3042-5.

21. Oscarson S, Alpe M, Svahnberg P, Nakouzi A, Casadevall A. Synthesis and immunological studies of glycoconjugates of Cryptococcus neoformans capsular glucuronoxylomannan oligosaccharide structures. Vaccine 2005; 23:3961-72.

22. Fleuridor R, Lees A, Pirofski L. A cryptococcal capsular polysaccharide mimotope prolongs the survival of mice 
with Cryptococcus neoformans infection. J Immunol 2001;166:1087-96.

23. Zheng M, Ramsay AJ, Robichaux MB, Norris KA, Kliment C, Crowe C, Rapaka RR, Steele C, McAllister F, Shellito JE, Marrero L, Schwarzenberger P, Zhong Q, Kolls JK. CD4+ T cell-independent DNA vaccination against opportunistic infections. J Clin Invest 2005; 115:3536-44.

24. Scheckelhoff M, Deepe Jr GS. A deficiency in gamma interferon or interleukin-10 modulates T-cell-dependent responses to heat shock protein 60 from Histoplasma capsulatum. Infect Immun 2005;73:2129-34.

25. Lin Jr-S, Yang C-W, Wang D-W, Wu-Hsieh BA. Dendritic cells cross-present exogenous fungal antigens to stimulate a protective CD8 $\mathrm{T}$ cell response in infection by Histoplasma capsulatum. J Immunol 2005;174:6282-91.

26. Wuthrich M, Finkel-Jiminez BE, Klein BS. Interleukin 12 as an adjuvant to WI-1 adhesin immunization augments delayed-type hypersensitivity, shifts the subclass distribution of immunoglobulin $G$ antibodies, and enhances protective immunity to Blastomyces dermatitidis infection. Infect Immun 2000a;68:7172-4.

27. Wuthrich M, Filutowicz HI, Klein BS. Mutation of the WI-1 gene yields an attenuated Blastomyces dermatitidis strain that induces host resistance. J Clin Invest 2000b;106: 1381-9.

28. Arruda C, Kashino SS, Fazioli RA, Calich VLG. A primary subcutaneous infection with Paracoccidioides brasiliensis leads to immunoprotection or exacerbated disease depending on the route of challenge. Microbes Infect 2007a;9:308-16.

29. Arruda C, Vaz CAC, Calich VLG. Aseptic cure of pulmonary paracoccidioidomycosis can be achieved after previous subcutaneous immunization of susceptible but not resistant mice. Microbes Infect 2007b;9:704-13.

30. Puccia R, Schenkman S, Gorin PA, Travassos LR. Exocellular components of Paracoccidioides brasiliensis: identification of a specific antigen. Infect Immun 1986;53:199-206.

31. Giannini MJ, Bueno JP, Shikanai-Yasuda MA, Stolf AM, Masuda A, Amato Neto V, Ferreira AW. Antibody response to $43 \mathrm{kDa}$ glycoprotein of Paracoccidioides brasiliensis as a marker for the evaluation of patients under treatment. Am J Trop Med Hyg 1990;43:200-6.

32. Puccia R, Travassos LR. The $43 \mathrm{kDa}$ glycoprotein from the human pathogen Paracoccidioides brasiliensis and its deglycosylated form: excretion and susceptibility to proteolysis. Arch Biochem Bioph 1991;289:298-302.

33. Travassos LR, Taborda CP, Iwai LK, Cunha-Neto E, Puccia R. The gp43 from Paracoccidioides brasiliensis: A major diagnostic antigen and vaccine candidate. In: Domer JE, Kobayashi GS (eds) The mycota XII, human fungal pathogens. Springer-Verlag, Berlin-Heildeberg; 2004, p. 279-96.

34. Almeida SR, Moraes JZ, Camargo ZP, Gesztesi JL, Mariano M, Lopes JD. Pattern of immune response to GP43 from Paracoccidioides brasiliensis in susceptible and resistant mice is influenced by antigen-presenting cells. Cell Immunol 1998;190:68-76.

35. Ferreira KS, Lopes JD, Almeida SR. Regulation of $\mathrm{T}$ helper cell differentiation in vivo by GP43 from
Paracoccidioides brasiliensis provided by different antigen-presenting cells. Scand J Immunol 2003;58:290-7.

36. Rodrigues EG, Travassos LR. Nature of the reactive epitopes in Paracoccidioides brasiliensis polysaccharide antigen. J Med Vet Mycol 1994;32:77-81.

37. Taborda CP, Juliano MA, Puccia R, Franco M, Travassos LR. Mapping of the T-cell epitope in the major 43-kilodalton glycoprotein of Paracoccidioides brasiliensis which induces a Th-1 response protective against fungal infection in BALB/c mice. Infect Immun 1998;66:786-93.

38. Travassos LR, Casadevall A, Taborda CP. Immunomodulation and immunoprotection in fungal infections: humoral and cellular immune responses. In: San-Blas G, Calderone RA (eds) Pathogenic fungi: host interactions and emerging strategies for control. Caister Academic Press, Norfolk, England; 2004, p. 241-83.

39. Pinto AR, Puccia R, Diniz SN, Franco MF,Travassos LR. DNA-based vaccination against murine paracoccidioidomycosis using the gp43 gene from Paracoccidioides brasiliensis. Vaccine 2000;18:3050-8.

40. Wolff JA, Ludtke JJ, Acsadi G, Williams P, Jani A. Lontterm persistence of plasmid DNA and foreign gene expression in mouse muscle. Human Mol Gen 1992;1: 363-9.

41. Jiang C, Magee DM, Quitugua TN, Cox RA. Genetic vaccination against Coccidioides immitis: comparison of vaccine efficacy of recombinant antigen 2 and antigen 2 cDNA. Infect Immun 1999;67:630-5.

42. Iwai LK, Yoshida M, Sidney J, Shikanai-Yasuda MA, Goldberg AC, Juliano MA, Hammer J, Juliano L, Sette A, Kalil J, Travassos LR, Cunha-Neto E. In silico prediction of peptides binding to multiple HLA-DR molecules accurately identifies immunodominant epitopes from gp43 of Paracoccidioides brasiliensis frequently recognized in primary peripheral blood mononuclear cell responses from sensitized individuals. Mol Med 2003;9:209-19.

43. Iwai LK, Yoshida M, Sadahiro A, Robert da Silva W, Marin ML, Goldberg AC, Juliano MA, Juliano L, Shikanai-Yasuda MA, Kalil J, Cunha-Neto E, Travassos LR. Tcell recognition of Paracoccidioides brasiliensis gp43derived peptides in patients with paracoccidioidomycosis and healthy individuals. Clin Vacc Immunol 2007;14: 474-6.

44. Marques AF, da Silva MB, Juliano MA, Travassos LR, Taborda CP. Peptide immunization as an adjuvant to chemotherapy in mice challenged intratracheally with virulent yeast cells of Paracoccidioides brasiliensis. Antimicrob Agents Chemother 2006;50:2814-9.

45. Del Negro G, Lacaz CS, Zamith VA, Siqueira AM. General clinical aspects: Polar forms of paracoccidioidomycosis, the disease in childhood. In: Franco M, Lacaz CS, RestrepoMoreno A, Del Negro G (eds) Paracoccidioidomycosis. CRC Press, Boca Raton, FL; 1994, p. 225-32.

46. Taborda CP, Nakaie CR, Cilli EM, Rodrigues EG, Silva LS, Franco MF, Travassos LR. Synthesis and immunological activity of a branched peptide carrying the T-cell epitope of gp43, the major exocellular antigen of Paracoccidioides brasiliensis. Scand J Immunol 2004;59: $58-65$.

47. Marschutz MK, Zauner W, Mattner F, Otava A, Buschle M, Bernkop-Schnurch A. Improvement of the enzymatic 
stability of a cytotoxic T-lymphocyte-epitope model peptide for its oral administration. Peptides 2002;23:1727-33.

48. Mattos Grosso D, de Almeida SR, Mariano M, Lopes JD. Characterization of gp70 and anti-gp70 monoclonal antibodies in Paracoccidioides brasiliensis pathogenesis. Infect Immun 2003;71:6534-42.

49. Marques da Silva SH, Queiroz-Telles F, Colombo AL, Blotta MH, Lopes JD, Camargo ZP. Monitoring gp43 antigenemia in paracoccidioidomycosis patients during therapy. J Clin Microbiol 2004;42:2419-24.

50. Silva SH, Mattos Grosso D, Lopes JD, Colombo AL, Blotta MH, Queiroz-Telles F, Camargo ZP. Detection of Paracoccidioides brasiliensis gp70 circulating antigen and follow-up of patients undergoing antimycotic therapy. J Clin Microbiol 2004;42:4480-6. 